\title{
The Convoluted Road of the Communist Party of Albania: 1941-1948
}

\author{
Etleva Babameto \\ PhD Candidate at the State University of Tirana \\ eva_babameto@yahoo.com
}

\section{Doi:10.5901/ajis.2014.v3n6p117}

Abstract

The Communist Party of Albania, later converted into the Labor Party and subsequently into the Socialist Party, was the only political party ever in Albania until the end of the Cold War leading it upon extreme isolation. As such, it stirs up special consideration. Precisely, this paper is focused on tracing the road accomplished by the Communist Party of Albania from its foundation in 1941 to its derogation into the Labor Party of Albania in 1948. It deals with factors which determined its foundation, its role in the National Liberation movement, its legitimacy, its relations with the Communist Party of Yugoslavia and their implications upon Albanian people. Moreover, the analysis of relations with the Communist Party of Yugoslavia places a significant role in the history of the Communist Party of Albania given that it was founded and controlled through the Yugoslav emissaries in line with the goals, interests and policies of the Communist Party of Yugoslavia. Yet, the journey of the Communist Party of Albania cannot be considered detached from national and international situation, namely the other resistance groups, the influence of international factor, strategic importance and attention paid to this country in the context of the Second World War and evolution following the developments both at national and international level in the course of the war years and beyond.

Keywords: Communist Party, occupation, opponent, foundation, Yugoslav Federation, relations, new partner.

\section{Introduction}

It is impossible nowadays to understand a certain people, his characteristics and evolution detached from his past history. This becomes even more indispensable at the beginning of the new millennium when contacts and relations between people throughout the world intermingle in all - round and complex ways.

Very often, the history and the fate of small peoples have been subdued to foreign powers interests and sometimes to greater neighboring countries. Within this context, we should not forget that these people went through long-lasting wars and efforts to survive and maintain their existence. However, each people's history has followed its path conditioned by specific internal and external factors. One of these peoples is Albania whose history presents her own characteristics through different phases.

The new Albanian State which came into being in 1912, had continuously to face up the vital issue of international recognition and defense of territorial integrity. However, due to its geographical position, profound influence of Ottoman rule and lack of a strong political identity, her fate was defined by long - term interests of Great Powers mainly in the Treaties of St. Stephan, Versaille, the Conference of Ambassadors in London, etc. Consequently, during the Balkan Wars, First World War and inter-war period, Albanian history passed through a bleak, obscure and often passive attitude which was obvious with its presence in none of the Treaties, Leagues or even Entantes.

It was the Italian invasion that caused Albania come out of her previous isolation and enter the stage of the Second World War. The domestic situation as well as the foreign occupation appealed to national consciousness to get transformed into national movement, a result of which was in 1941: the foundation of the first political Party in Albania the Communist Party.

\section{Internal and External Factors on the Eve of the Communist Party of Albania (Cpa) Foundation}

\subsection{A general overview of the domestic situation}

Italian occupation of Albania which took place on the $7^{\text {th }}$ of April 1939, found this country extremely backward, poor and illiterate, where $85 \%$ of the population consisted of peasants and $15 \%$ of citizens. All these belonged to 3 different religious beliefs: $70 \%$ muslims, $20 \%$ orthodox and $10 \%$ catholics (Kissinger, H. 1999, p. 38). 
But more distinctly, people in Albania were divided into 2 groups: the ghegs in the north and the tosks in the south. Obviously, agriculture constituted the work of $80 \%$ of the population; more than half of arable land was landowners' propriety and almost half of the peasants were landless. The primitive agrarian techniques caused Albanian people to be the least productive of Balkan peasants. Industry, which during the Italian occupation constituted $5 \%$ of the national incomes, was one of the most backward as well.

There were no industrial centers except some small workshops to provide household needs. There were no Universities but some elementary and high schools into the main cities. On this context, it is evident that although the Albanian people treated the Italians with hatred, they were keener on preserving local authority especially in the north through tribal chiefs (Durham, E. 1991, p. 451). Hence, being scattered and disorganized, they lacked a common and central authority that could lead them in a strong and effective movement against the Italian occupation.

Until this period, Albanian people were little familiar with communist ideas.

These ideas had begun to come out during the first half of 1930' when Comintern sent some communist-trained Albanians (who had fled after the Fan Noli's government downfall) to set up some communist cells. Most prominent of these communists, was Ali Kelmendi who managed to help establish some communist groups but their activities were no more than spread leaflets, cut off wires and organize demonstrations. However, Ali Kelmendi was forced to flee due to his inability to establish strong communist bases.

Among the already existing communist groups, the most important were: 1-the group of Korca, 2-Tirana, 3Shkodra (Fischer, B. 1999, p. 172). The group of Shkodra consisted of mainly high-school pupils and youngsters who supported the idea of a working-class socialist revolution while there was no working-class in Albania. The 2 other groups consisted more of middle-class intellectuals and appealed to Albanian people about a general resistance against occupiers. Among these groups, the most influential was that of Korca which had a better mixture of intellectuals and workers and whose activity was better organized.

But these groups proved unable to cooperate with each - other, undertake any serious steps for organizing and creating a proper Party. What characterized them, was dissention, friction and competition for following different supportive bases and elaborating different strategies to fight the foreign occupation. On this historical background, it should be noted that until that time, no political Party was ever created in Albania.

\subsection{The Foreign Occupation - An Incentive Factor of National Awakening}

As mentioned above, Albania was under Italian occupation since the $7^{\text {th }}$ of April 1939 whose final aim was the annexation of Albania. It issued a Constitution which was designed to institutionalize its dominance (Stavrianos, L. 2000, p. 795). Italy had mainly strategic interests in Albania for a further expansion into the Balkans and for establishing a part of Italian population into this country. This occupation resulted in a resistance movement which gradually started to increase markedly.

Following her political aims with Greece and Yugoslavia and her internal issues with Albania, Italy proclaimed "The Greater Albania" which would include Kosovo and Epirus. This policy had a strong and dual impact over Albanian people. More specifically, as a result of the Italian policy, Albanians in Kosovo saw them as liberators who realized their historic aspirations (Vickers, M. 1995, p. 145). They were allowed to use the Albanian language, Albanian media, police forces and keep arms. This situation was quite different in Albania where Italians continued to be considered as hostile enemies, as occupiers of the Albanian land against whom the national movement was inflicting considerable damages. One of the results of this movement was also the newly created communist Party.

\subsection{The Impact of External Background on the New Political Developments in Albania}

The advent of Second World War found Albania under Italian occupation. This fact enabled her to enter the international stage as an active actor whose only aim was the defeat of occupying forces and maintenance of her territorial integrity.

As regards the external background, at that time communism was rapidly spreading all over Europe under Soviet leading role which aimed to give Eastern Europe a Soviet model shape (Laqueur, W. 1996, p. 11). There were no Soviet interests in Albania except establishing communism as a part of the Balkan region; nor were there any Soviet armies in Albania. On this framework, there is evidence that the first Albanian communists went to Moscow and formed the Revolutionary Committee which became part of Balkan Federation of communist Parties. At this period, Yugoslav interests, deeply related to communist movement, will soon be involved into Albanian issues.

Similarly, the other neighboring country - Greece which was swept by all-round communist movement too, 
continued to maintain her territorial claims of southern Albania. Meanwhile, British interests in Albania were based on short-term military goals, namely to support those resistance groups that were actively engaged in the struggle against the Axis forces.

\section{The Foundation of CPA - The First Ever Political Party in Albania}

\subsection{The Foundation of CPA as a Political Offspring of Yugoslav Communist Party (CPY)}

It is a known fact that until 1941 no political party existed in Albania. It was also the only Balkan country where communism appeared later than in other countries, but nevertheless in no more than 5 years it legitimized its victory. Actually, the Communist Party of Yugoslavia decided, through the Regional Committee of Kosovo in the meeting of Vitomirica on 11 October 1941, the delegates, Miladin Popoviç and Dushan Mugosha, to participate in the founding meeting of the CPA as well as the program to be presented there (Bislimi, D. 2003, p. 89-91). When the two Yugoslav communists came in Albania in October 1941 what they found out, were small groups working individually, detached of mass people and objecting each other. "We could find anything among these groups except for communist ideas" (www.ezboard.com) - were their first opinions. They would immediately put the situation under control in Albania and impose their cult (Bislimi, D. 2003, p. 89-91). They spent days contacting these groups, and managed to unite them in 1941 and create the first Albanian political party - The Communist Party. The participants in these meetings were from Korca and Tirana groups - totally 15 communists - all middle class intellectuals except Koci Xoxe - a tinsmith (Vickers, M. 1995, p. 146).

The Yugoslav emissaries elected a committee of 7 members, and proclaimed the foundation of CPA. In their program, they excluded the national issue and ranked as their main points: freedom from occupation, land reform, general economic and social change. Enver Hoxha who by then had not been one of the main leaders, was appointed under Yugoslav proposal Commander-in Chief. What marked the anti-national character of this Party, was the Kosovo issue. In one of the points, the program of CPA declared "not to forget the danger coming from the influence of nationalism" (www.pasqyra.com). Evidently, this statement refers to Kosovo which shortly before the CPA foundation was joined to Albania under the Italian policy of Greater Albania. Thus the Party's program did not include the national issue despite the impact of this sentiment among Albanians at that time and the false declarations of some Albanian communists about their implication on national issues as well. The Communist Party has constantly repeated Miladin Popoviç's words that "the Kosovo question does not regard CPA but CPY" (Akademia e Shkencave te Shqiperise, Instituti i Historise, 1997, p. 207). This background in Albania was in line with the situation in Kosovo where the Yugoslav communists failed to recruit communist elements to create communist cells in Kosovo by promising them to pursue a policy based on self-determination principle. Presumably, to conform to such a policy in Albania they had found the reliable person: Enver Hoxha.

He was the one who could be identified with the Communist Party itself. Everything related to this Party, its activity and influence in Albanian history, relates to his name as an obedient and accurate implementer of the Yugoslav policy. He was born in Gjirokastra, southern part of Albania in 1908, the son of a middle class tosk family (muslim land owner), attended French Lycee in Korca, received a scholarship to study in Montpelier, from there he moved to Paris and then to Brussels but he took a diploma in none of the universities. In 1936 he returned to Albania to become involved into the communist movement of that time until his meeting with the Yugoslav communists.

\subsection{The Role of CPA in the National Liberation Movement in Albania}

It is so controversial that the Communist Party, the only one already exciting during the Second World War, had nothing to do with the national character, was bound to serve to Yugoslav interests and, nevertheless managed to legitimize its victory under the so-called national liberation struggle. Several factors account for this reality. First there is the Yugoslav predominance in Albania during the war. The other factors, internal issues and foreign influence, will be dealt with in the following parts.

The newly formed CP had now a provisional Central Committee with a pro-Yugoslav Secretary General and Yugoslav advisers who immediately started their work to increase the number of party members which by than was about 130 (Fischer, B. 1999, p. 176). Under the slogan "Death to Fascism, Freedom to People" and based on propaganda of national liberation struggle, the Communist Party appealed to popular masses to recruit as many people as possible. They established local committees by initially proclaiming that membership was free for anyone who wanted to fight the 
enemy and it excluded the party line. Emphasis was nevertheless put on students, youth, craftsmen, intellectuals, and then reaching to peasants who constituted the majority of population. CPA issued its first clandestine newspaper, the "Voice of People" which influenced the spread and implementation of communist ideas by encouraging people to wage a popular struggle.

Under Yugoslav presence and management acknowledged by Hoxha's words "when we founded our party the support of Miladin and Dushan was decisive because I was myself inexperienced to deal with party organization" (Fischer, B. 1999, p. 176), the CP held a conference in Peza in September 1942 which was controlled by communists and in which were invited individuals of Balli Kombetar (BK, the National Front), - the other opponent group (Smirnova, N. 2004, p. 237-239). These groups agreed to establish a National Liberation Front in order to mobilize all Albanian people in their common war against the occupiers. Also, it was decided to set up national liberation councils and partisans units. This conference discussed the form of the regime that would be established after the war. The idea of democratic republic was avoided by communists as inappropriate 'given the actual situation'. It was quite clear now for communists to lead a purging campaign against the internal opponents as well.

In March 1943, CPA held the Conference of Labinot in which under Tito's message CP was asked to purge its rallies by fractions elements (Vickers, M. 1995, p. 150) and recruit more peasants since at that time there was no industrial working class. The major decision at this conference was the establishment of the Albanian National Liberation Army modeled after Tito's National Army. This army had the distinct advantage of having a very youthful membership and a considerable membership of women too, thus increasing its popularity. Later, in the Plenum held in Berat in November 1944, some communists would oppose Hoxha's attitude for supporting Yugoslav ideas rather than Albanian ones. He would confess that the Central Committee, he himself as well as the Political Bureau, were elected by Miladin Popoviç and that they had no idea about the political structures of the Party (Dervishi, K. 2006, p. 542). At the same time through secret relations with Tito, he continued his attempts to eliminate 'anti communist' (anti-Enverist) elements within his party and outside it too which meant eliminating anti-Titist elements. An important step for the CPA was the Congress of Permet in May 1944 which proclaimed the anti-fascist council of national liberation of Albania, modeled after that of Yugoslavia. The committee elected there, was recognized as the provisional governmental executive. This Congress formed the basis of the constitution of the post-war Albanian state. Obviously, Yugoslavia was near its final aim: to include Albania under its federation, of what Stalin would refer to as the "swallowing" of that country (Jelavich, B. 1983, p. 324).

A very significant movement of Tito's plans is the period before the final withdrawn of german forces. Tito asked two Albanian Divisions to help Yugoslav army force the Germans out. In line with his policy, this was to prove to the Kosovo people that Albania and Yugoslavia became unified; therefore it wouldn't be the case to ask their joining to Albania (www.azboard.com). Besides, being aware that some of Kosovo people had joined the germans to escape the serbs' atrocities, Tito pushed the Albanian battalion against Albanian people thus leading to a conflictual situation. Yet, Hoxha did not hesitate to comply with Tito's instructions.

\subsection{CPA challenges its domestic opponents: "Balli Kombetar" and "Legality"}

Along with leading National Liberation movement the CPA led a relentless struggle against domestic rivals. Meanwhile, some nationalists being concerned with the foundation of CPA and its gradual growth, decided to form the anticommunist organization called Balli Kombetar. It consisted of tosk population, mainly landowning beys and some other political emigrants who had left the country after Zog seized power. This organization proclaimed a very advanced program advocating for the liberation of country from foreign occupation, establishment of a democratic Republic and creation of ethnic Albania, therefore including Kosovo issue (www.Pasqyra.com). They advocated western ideas and believed that Allied forces would support them rather than communists. Nevertheless, it was characterized by fragmented groups which operated under individual requests, uncoordinated plans and failed to attract the support of broad masses.

Under these circumstances, on the $2^{\text {nd }}$ of August 1943, was held the Mukja Conference where different opponent groups managed to join and decide to leave aside their friction on behalf of the National Liberation issue and create a National Committee for the Salvation of Albania; Also it called for the "Ethnic Albania". As to the problem of who would take the power, both groups agreed to solve through a plebiscite after the war.

Alarmed, the Yugoslav representatives asked Hoxha to denounce the agreement while Popoviç, immediately after reading the decisions of this Conference, said: "This union cannot be accepted. We get stronger by attacking them on their head (BK) and not by joining dogs. Then, that Ethnic Albania, damn it..." (Dezhgiu, M. 2001, p.48).

Only 3 days after the agreement, Hoxha denounced it as a dark spot in the history of the Albanian people and the 
National Front as a hostile organization which demanded the same "Greater Albania" as Italy had called for, and members of the Balli Kombetar as traitors who demanded to challenge the CPA - the leader of the national movement (Ballvora, Sh. 2004, p. 174). Following denouncement of the Mukja agreement, Abaz Kupi, a pro-Zog northern chieftain, disappointed by CP and the National Liberation Front he had been participant, detached from them and founded in September 1943, another organization - "Legality". This organization consisted of a small number of members who claimed the return of Zog monarchy and operated in the northern part of Albania, mainly in Mati and Kruja region. Its program maintained for the struggle against occupiers, national union upon the borders of ethnic Albania, support to the policy of the Great Allies (Great Britain, United States of America and Soviet Union) and restoration of the parliamentary constitutional monarchy as it was before 7 April 1939 (Butka, U. 2006, p. 265).

In view of this situation, in September 1943, CPA held the $2^{\text {nd }}$ Conference in Labinot in which it proclaimed itself as the only leading force for the national liberation struggle and based on the concept that "anything that is not communist is to be called fascist and all those outside the National Liberation Front as collaborators" (Butka, U. 2006, p. 265), it announced its open objection against Balli Kombetar and Legality and called for war against them.

By the end of the SWW, according to some British Liaison Officers (BLO) in the field, this organization resulted to be far weaker, disorganized and lacked disciplined leadership and collaboration with other resistant groups. Ultimately, these two groups did not constitute any real, serious threat to the CPA activity.

\subsection{CPA Favorable Position between Foreign Occupation and British Presence}

Following the collapse of the Italian occupation, the German occupation of Albania in September 1943, had a strong impact on the National Liberation movement. Since this movement was increasingly strengthening its credibility as the only real fighting force, the German occupiers applied their policy "Divide et Impera" trying to put different resistance groups against each-other (Neubacher, H. 1956, p. 105-121). They claimed to be temporary in Albania and supported an independent and neutral coalition government within the frame of the German interests. Under this policy and fearing the communist threat, some of Balli Kombetar members joined the German forces. Naturally, this was one of the weak points of Balli Kombetar as it served the CPA to declare them as traitors, as enemy collaborators against the Albanian people.

British presence in Albania placed CPA into favorable position as well. Its role in domestic situations regards two periods: before the liberation of Albania in November 1944 and after it. During 1943-1944, the British Foreign Office sent its SOE missions in Albania to gather information about the situation there and provide assistance to encourage the Albanian resistance (Barker, E. 1976, p. 174-179). They were attached and contacted with CPA members, Balli Kombetar and Legality and concluded that the communists leading the National Liberation War were almost the only reliable force against the Germans (Puto, A. 1987, p. 203). Nevertheless, the British Foreign Office (BFO) took different controversial messages with regard to whom to support. Under these circumstances, the BFO decided that its short-term military aim rather than long-term political aim was to support whatever anti-Axis resistance movement, which meant the NLW led by communists. "Although British moral and material support was not quite decisive, they proved very helpful and consisted of arms, foods, clothes, money and training of partisans" (Puto, A. 1987, p. 203).

Since 1945, the British policy diverted against communist regime. It recruited and trained anti-communist elements who were sent into Albania after 1945, but their missions failed since a British officer, Kim Philby, leaked the information to the Soviet Union (Puto, A. 1987, p. 203). Consequently, anti-western campaign in Albania increased at that time and culminated in 1946 with the Corfu channel incidents. Four British ships passed on waters claimed by Albanian authorities to be theirs and struck into mines. British party appealed to the International Court of Justice which asked Albania to pay the reparations (which Albania didn't). Meanwhile, Britain and USA opposed Albanian admission to the United Nations and supported Greek claims to territories in southern Albania (Jelavich, B. 1983, p. 331). Shortly after, there was no more British presence in Albania.

\section{The Relations between CPA and Cpy Until 1948}

\subsection{The Liberation Day - Great Expectations in the History of the Albanian People}

Finally, on 29 November 1944 Enver Hoxha proclaimed the liberation of the country. Due to Yugoslav political and ideological leadership, based on national principle and broad-mass participation, the CPA liquidated its internal opposition and finally established its own power.

First, to meet the peasants' demands and fulfill its obligations, the CPA initiated the land reform under the slogan: 
"The land belongs to those who cultivate it". Accordingly, poor peasants were granted a piece of land and landowners were expropriated. Meanwhile, the industry and every private enterprise became subject to nationalization process. Steps were taken with regard to education and culture too, which were immediately politicized by putting emphasis on historical values and national liberation struggle.

Shortly after the liberation, in December 1944, Albanians elected a new Popular Assembly which banned the monarchy and transformed Albania into a "People's Republic" (http://en.wikipedia.org/wiki/C_andpost_CAlbania). It issued a new Soviet-style constitution similar to Yugoslav model, established a unicameral legislative body dominated by Communist Party whose members held all the government posts too and appointed Enver Hoxha as the Party First Secretary, Prime Minister, Foreign Minister, Defense Minister and the Army's Commander-in Chief. Supposed to be free elections, the right for candidate was appointed only to members of the National Democratic Front, which implied communists. Since the Allies had never recognized an Albanian government in exile, this fact presently suited to the new Albanian government to acknowledge that it recognized no other government, and, nor did it allow any other Party foundation.

In order to maintain and strengthen his political power, Hoxha started an extremely cruel liquidation campaign against those he considered "the class enemies" (www.Pasqyra.com). Show trials, imprisonment, killing, disappearance, internment and labour camps made up the background of the new state. "No ruling communist Party thrived on a diet of purges like the CPA began in 1942" (Glenny, M. 2000, p. 561). In this framework, the relations between Albania and Yugoslavia become more open.

\subsection{CPA-led Albanian People towards Joining Yugoslav Federation}

The establishment of the communist dictatorship went closely associated with the implementation of a policy which aimed the union of Albania and Yugoslavia. According to a communication of July, the $3^{\text {rd }}, 1946$ over the treaty of friendship and mutual assistance between the two countries (Ndreci, P. Malltezi, L. 1996, p. 43), this policy was reflected through agreements and directives about common companies, customs union, unify the currencies, establish a common commission of coordination, unify the armies for a common defense, and finally, through federal basis joining both communist Parties and realizing the political union of both countries. Editorial of the treaty between 2 countries about plans coordination, customs union and unifying currencies dates back November, $27^{\text {th }} 1946$ (Ndreci, P. Malltezi, L. 1996, p. 62).

The 5-th Plenium of February 1946 (Ndreci, P. Malltezi, L. 1996, p. 27) marked the liquidation of democratic tendencies noted among the Party members. In this Plenum, Hoxha would confess that "The union with Yugoslavia is an indispensable condition about the existence of our country". So complete was the Yugoslav predominance over Albania that the latter was not invited to the founding meeting of Cominform in Poland in September 1947 (Crampton, R.Y. 2002). Instead, it was supposed to be represented by the Yugoslav degelation.

The Kosovo issue which was supposed to be settled after the liberation, witnessed the anti-national character of the CPA in the Plenum of December 1946 as Hoxha put it: "Yugoslavia is more advanced and prosperous than we are. Therefore, our concern is that Kosovo remain its part since Yugoslavia is a decisive factor for establishing democracy in the Balkans" (Ndreci, P. Malltezi, L. 1996, p. 12). Furthermore, the Interior Minister Koci Xoxe, authorized officials of U.D.B. (under full Hoxha's knowledge) the execution of more than 1.000 Kosovars who had fled from Kosova to escape Serb atrocities ('Flamuri' journal, January, 1950).

During the 1947, Yugoslavia opted for accelerating the process of federal union between the two countries as a necessity with regard to its independent foreign policy. Relevant to this, the Central Committee (CC) of CPY made an official note of complaint against the CC of CPA on the grounds of a second anti-Yugoslav line in Albania. Evidently, a certain Party could not complain and impose its own remarks over another one unless there is a subordinate relation between them, and presumably this was the case in Albania. On this matter, Hoxha wrote to Tito: "We are fully committed to reach the final union under the federation" (Ndreci, P. Malltezi, L. 1996, p. 415). To settle this situation and retain his personal position, Hoxha justified the Yugoslav complaints on delays concerning cooperation and union between the two countries, as an undermining act of the class enemy and held a Politburo meeting(Ndreci, P. Malltezi, L. 1996, p. 396) to shift the responsibility among other Party members.

Under these circumstances, Hoxha paid a visit to Bulgaria and shortly after, held a speech before his people where he proclaimed the union of the two countries under Yugoslav Federation (Ndreci, P. Malltezi, L. 1996, p. 355). During this period, however, Soviet - Yugoslav conflicts would start to have a strong impact on CPA policy. 


\subsection{Enver Hoxha - the First "Anti-Titist" leader of the European Communist Countries}

Following the Yugoslav accusations against Albanian government, the 8-th Plenum of Mars 1948 (Ndreci, P. Malltezi, L. 1996, p. 212), sought to meet their requests. The main issues on its agenda was the analysis of anti-national and antiYugoslav activity of class enemy (allegedly Nako Spiro and his supporters) and set strategies for accelerating the process of union with Yugoslavia. When still, Stalin and Tito were on very good terms, Stalin sent a cable to Tito declaring that "subsequent mutual relations with Albania should aim at its joining the Balkan Federation" (Hrushov, N. 2004, p. 129).

Meanwhile, the conflict between Stalin and Tito regarding Tito's independent foreign policy came into the open. Stalin, who feared Tito's appetite for leading a Balkan Federation, declared him as anti-communist and finally their relations broke. This situation was to have a strong impact on Albanian policy as well. It was only 4 days after the 8-th plenum, due to finalize Albanian union under Yugoslav Federation, that Hoxha found himself in an awkward position: Either with Stalin who maintained the international communist leading role or with Tito who had strong basis in Albanian policy?! Enver Hoxha decided to denounce the 8-th Plenum as a dark spot which aimed the annexation of Albania under Yugoslav Federation, Tito as an imperialist and anti-communist and himself as the most determined anti-Titist and antiYugoslav opponent (Ndreci, P. Malltezi, L. 1996,). Responsibility would now fall over Koci Xoxe, one of the closest collaborators of Hoxha pro-Yugoslav policy, followed by a purging campaign against "Xoxe group" as a class enemy.

\section{The Need for Diversion: From the Comunist Party into the Labor Party of Albania}

\subsection{Meeting a new partner - the Soviet Union}

It was not by accident that Hoxha shifted his subordination to Soviet Union. Until 1948, Albania posed no direct interests to Soviet Union except for establishing communism there. Previously, it had even recognized Tito the "blank check" right (Ndreci, P. Malltezi, L. 1996, p. 15) to follow its own policy in relation to Albania. After the final break with Tito, Stalin's concerns in Albania consisted of merely having an anti-Titist Balkan country that would undermine Tito's policy of Balkan Federation. In a conversation in Moscow in 1948 with Milovan Djilas, a Yugoslav communist, he would say: "I had hoped that the Albanians were at least a little Slavic" (Petrovich, B. M. 1962, p. 78-79, 133-138, 143-147).

Alternatively, these circumstances, met with Enver Hoxha's interests. First, the Soviet Union represented the highhanded role in the international communism and this was a very good opportunity for him to maintain his leading position. Second, since the SU posed no direct interests in Albania and was not a neighboring country, this was the case to separate from Yugoslav complete subordination and lead a policy of his own which consisted of using whatever means that secured him leadership.

\subsection{Building a New Era - The Most Isolated Communist Country}

Although the Soviet Union was the only foreign state to have a full Diplomatic mission in Tirana, it was argued that the price of separation from Yugoslavia inclined further subordination upon the Soviet Union (Vickers, M. 1995, p. 175). Nevertheless, the fact that the Soviet Union had no common borders with Albania, implied that it was difficult for Moscow to exert pressure on Tirana but it was easier for Hoxha to lead his isolation policy towards the Albanian people. Given the actual circumstances, Albania entered an orbit around Soviet Union which in turn made up for her loss of Yugoslav aid.

Consequently, to help Albania recover from its critical situation, the Soviet Union sold its exports half of the imported goods prices. Also, it adopted centralized planned economy with emphasis on self-sufficiency in heavy industry. Regarding agriculture, the process of collectivization and an ambitious program of electrification already started. State institutions continued to be equivalent with Party's institutions thus exerting absolute authoritative control over all aspects of society. In addition, a ruthless campaign continued against all those Hoxha considered as possible rivals to his power. In this framework, in November 1948 at the first Party Congress, the Communist Party of Albania was renamed, at Stalin suggestion, the Labor Party of Albania thus opening up a new era in the history of the Albanian people.

\section{Conclusion}

The CPA, founded on 8 November 1941, was the only political Party that has ever existed in Albania until the end of the Cold War period. Although Albanian people was little familiar with communism at that period, it spread fast and within five years managed to establish its legitimacy which remained deeply rooted for well fifty years. Founded upon and controlled 
by the Yugoslav emissaries, CPA adhered to CPY instructions and interests which well suited to Yugoslav policies regarding Albania until 1948 when it diverted and derogated into the Labor Party of Albania.

Domestically, CPA managed to become the leader of the National Liberation movement against the Italian and German occupiers, managed to challenge its rivals, - Balli Kombetar and Legaliteti, which in turn, both proved unable to become a decisive factor (some elements even collaborated with the germans) in this struggle and gain power, and ultimately, finalize its victory by coming to power on 20 November 1944. At international level, the Allies considered CPA as the only resistance group seriously fighting against the Axis in Albania and provided their support to it which proved really helpful.

The role and activity of CPA was identified with Enver Hoxha himself who maintained his personal leadership until his death. His only policy was to use whatever means and ways serving him to maintain his position. He succeeded by following Yugoslav policy to the detriment of the Albanian people and by leading a ruthless purging campaign against all those he considered possible rivals. As a self-centered and a fervent anti-nationalist, Enver Hoxha sought to undermine the Albanian existence by including it into the Yugoslav Federation; he disregarded every Albanian value, left Albania extremely poor and backward, and throughout his power, led it under complete isolation, destroyed its intellectual potential and undermined its human dignity.

\section{Bibliography}

Barker, E. (1976). "British Foreign Policy in South East Europe in the Second World War", The Macmillan Press LTD, Hrushov, N. (2004). "Une nuk jam gjykates", ombra GVG

Dezhgiu, M. (2001). "Shqiperia ne Lufte 1939-1944", Globus R. Tirane

Bislimi, D. (2003). "Emisarwt Jugosllave - Tutore te Udheheqesve te CPA", Kerkime Albanologjike, 30-2000, Prishtine

Akademia e Shkencave te Shqiperise, (1997). Instituti i Historise, (1-4) Tirane

Puto, A. (1987). "Neper Analet e diplomacise Angleze" - Paper;

Ndreci, P., Malltezi, L., (1996) "Marredheniet ndermjet Shqiperise dhe Jugosllavise gjate viteve 1945-1948", "Gjergj Fishta", Tirane

Neubacher H. (1956). "Sonderauftrag Südost 1940-45: Bericht eines fliegenden Diplomaten (Göttingen)", Perkthyer nga Gjermanishtja nga Robert Elsie

Durham, E. (1991). "Brenga e Ballkanit", "8 Nentori", Albanian edition

Dervishi, K. (2006). "Historia e Shtetit Shqiptar 1912-2005", Shtepia Botuese 55, Tirane

Hupchick, P. (2004). "The Balkans from Constantinople to Communism", Palgrave Macmillan;

Yelavich, B. (1983). "History of the Balkans", Vol. 2, Cambridge University Press

Fischer, B. (1999). "Albania at War", Hurst \& Company, London

Kissinger, H. (1999). "Diplomacia", The Public Press of the Writers

Laqueur, W. (2003). "Europe in our Time: a History 1945 - 1992", Dituria

Smirnova, N. (2004). "Historia e Shqiperise gjate Shekullit XX", "ideart", Tirane

Stavrianos, L. S. (2000). "The Balkans since 1453", Hurst \& Company, London

Zinner, P. (1956). "National Communism and Popular Revolt in Eastern Europe", New York

Crampton, R. J. (2002). "The Balkans since the Second World War", Pearson Education

Ballvora, Sh. (2004). "Zhvillimet politike ne periudhen e Luftes Antifashiste Nacionalçlirimtare", Dituria, Tirane

Glenny, M. (2000). "The Balkans 1804 - 1999: Nationalism, War and the Great Powers", Granta Books, London

Vickers, M. (1995). "The Albanians, A Modern History", London-New York

\section{Internet sources}

www.Pasqyra.com

www.ezboard.com

www.emulateme.com/history/albhist/h.t.m.

http://en.wikipedia.org/wiki/C_andpost_CAlbania 